Experiencing Television Fandom: Notes on the Tension

Between Singularization and Massification in Brazil ${ }^{1}$

\title{
Maria Claudia Coelho
}

Universidade do Estado do Rio de Janeiro

Keywords: Fandom, modernity, Brazilian culture

\begin{abstract}
This paper examines the way fandom is experienced in Brazil. The analysis is based on fan discourse as it appears in letters sent to actors and actresses who work at Rede Globo de Televisão, the major Brazilian TV network, situated at Rio de Janeiro. The analysis proceeds along two axes: the attempts made by fans to distinguish themselves among the crowd and the frequent use of romantic discourse to express their feelings for their idols. Both issues are understood as 'singularization strategies', whose recurrence creates a paradox: it is precisely the effort to distinguish themselves that makes the fans alike. This paradox is used as a way to discuss how the tension between singularization and massification is experienced in Brazil, contributing to the understanding of how one of the main trends of Western modern life appears in South America's largest country.
\end{abstract}

\section{Introduction}

In 1991, a Brazilian pop band wrote a song with lyrics that described life for poor people. ${ }^{2}$ Its chorus line was: 'I belong to the people, I'm just a John Doe'. It soon reached the hit lists and the band performed it many times at television variety shows. During these performances, the band leader would invite someone from the audience to join them on stage to sing and dance. He would also give him the microphone for a few moments, always during the chorus. The fan had his fifteen seconds of fame, during which he sang out loud in national broadcasting that he was a John Doe. I watched this scene several times, both on television and live during a concert. And it always struck me because of its power to synthesize what I suggest to be the essential paradox of the experience of fandom: the wish to have one's singularity recognized, but however expressing this wish as part of a crowd.

Westminster Papers in Communication and Culture (C) 2005 (University of Westminster, London), Vol. 2(2): 97-112. ISSN 1744-6708 (Print); 1744-6716 (Online) 
This article examines the way fandom is experienced in Brazil, focusing on how the tension between massification and singularization - dramatized in the scene above - appears in Brazilian society. It therefore can be seen as an attempt to discuss how a classical issue which mass media studies have since long been devoted to appears in a particular phenomenon of Brazilian mass culture. Umberto Eco (1979), in his outline of mass media debates, pointed out that to offer their readers some hope that they could escape massification seemed to be one of the effects 'apocalyptical' theories might have. Edgar Morin (1980) has also shown, in a study about issues of fandom and celebrity focusing on the Hollywood star system, that celebrities thrived on offering fans a way to express their individualities, while at the same time promoting feelings of loneliness. The issue of individuality in mass culture societies - the tensions, ambiguities and paradoxes it its embedded in - has thus since long been a major concern to those devoted to its understanding. It is this path that this study pursues in order to understand its features in the particular phenomenon here addressed.

The article also intends to use Brazilian experience of fandom as a means of reflection on the possibility of resorting to European sociological interpretations of modernity to explain aspects of South America's contemporary societies. This theoretical agenda is of relevance both to the understanding of the place these societies occupy in a globalized world and of the way Brazilian sociological thought has been establishing dialogues with European sociological trends. After all, if it is analytically profitable to resort to Georg Simmel's and Zygmunt Bauman's interpretations of modernity (just to anticipate two sociologists whose work will be referred to below in this paper) to understand issues of Brazilian culture, where does Brazil stand in contemporary Western world? Or, to put it as Claudia Barcellos Rezende (2004) did: is Brazil a Western country?

In order to pursue these points, the article is divided in four sections. In the first one, I expose features of what is commonly referred to in Brazil as a 'star system', that is, the culture production system organized around Rede Globo de Televisão, having in its center the production of telenovelas. The second section introduces the data - a set of 280 fan letters sent to two stars of telenovelas - and discusses methodological issues. It is followed by an analysis of aspects of the experience of fandom as they appear in these letters. Although fandom and celebrity are relatively understudied in Brazilian social sciences, it is possible to identify as a trend among research devoted to understanding fame case studies of particular forms of fan-idol relations, among which the present research may be included. ${ }^{3}$ Recent examples of this kind of work are Patrícia Coralis's (2004) thesis on a Brazilian virtual fan club of North American pop singer Madonna and Rosana da Camara Teixeira's (2004) dissertation on fans of the Brazilian pop singer Raul Seixas. Both studies focus on how fans elaborate their identities and sociability, virtual and real. Here, I draw upon a research undertaken between 1991 and 1993, 
which developed into my $\mathrm{PhD}$ dissertation in Sociology to Instituto Universitário de Pesquisa do Rio de Janeiro in 1994. ${ }^{4}$ I examine fan discourse focusing on the ubiquity of the yearn for singularization, discursively expressed in two strategies which appear frequently in these letters: the self-presentation of the fan as a 'number one fan' and the use of romantic discourse to express their feelings for the idol. 5

The fourth section of this article is an attempt to establish a dialogue between an important trend in Brazilian sociological thought - the effort to explain Brazilian singularity through the place occupied by hierarchical features in this society - and some classical and contemporary interpretations of modernity devoted to the issue of individuality's configurations in mass societies (namely those of Simmel and Bauman). The limits and possibilities of establishing such a dialogue are explored in order to achieve a better understanding of Brazil's place in contemporary Western world.

\section{A Brazilian Star System: Rede Globo de Televisão}

Rede Globo de Televisão (Globo Television Network, referred to as Globo) was founded in 1965. Almost throughout its history, it has been the main television network in Brazil, currently having 115 affiliated networks spread all over the country and reaching over 99\% of Brazilian territory (according to a research produced by Globo in 2003). It is the center of a communications corporation which includes newspapers, magazines, radio stations, cable TV and internet services. It also includes a synergistic production of movies and the transformation of productions originally made for television into films. Its effects can be felt on the theatre too, for to cast a Globo star in a play is most of the times an essential condition for its success.

Globo is a network known all over the world due to its main product: telenovelas. Telenovela is a television genre that combines features of several literary genres, mainly melodrama. In its Brazilian version developed by Globo, it can last up to nine months, holding audience rates which can reach, in its peaks (such as the last chapter of a successful telenovela aired at prime-time), over $90 \%$ of the national audience.

Globo's success may be attributed, according to Sílvia Borelli and Gabriel Priolli (2000), to the consolidation of a pattern of programming developed for primetime: a combination of information and fiction, which, in actual programming, translates into a news cast aired between two telenovelas. This pattern accounts for a mixed audience, which has led, in Brazilian television audience habits, to a shared viewing among family members. This pattern can also be held accountable for the concentration of publicity funds in these two genres. Again, in order to give a 
rough idea of how profitable this pattern has proved, Borelli and Priolli provide an example based on a very successful telenovela, aired at prime-time between 1985 and 1986 (Roque Santeiro): its estimated total production cost was two million dollars (about ten to fifteen thousand dollars per chapter), while each thirty-second commercial spot cost almost twenty thousand dollars. These audience rates and estimated profits allow us to think of Globo's telenovelas as the center of a Brazilian star system. As Borelli and Priolli put it:

...Globo has managed, throughout its history, to gather a cast of professional artists and technicians, an actual star system, able to mobilize other media, stimulate competition, disrupt public and private spaces' limits, redefine characteristics and meanings of intimacy, create mass culture mythologies and draw imaginaries in contemporary life's context. $(2000,31)$

The centrality of Rede Globo for the possibility of talking about a Brazilian star system is undeniable. Although it certainly revolves around telenovelas, it spreads to a number of mass communications products, such as other television shows and celebrity magazines. ${ }^{6}$ Some of these products belong to Globo's communications conglomerate, devoted to the promotion and discussion of telenovelas and other teledramaturgical genres. This is the case of a show like 'Video Show', aired six times a week (Monday to Saturday), which, among other things, presents backstage scenes from Globo's productions, such as comical mistakes taking place during the recording of scenes. It is also the case of a celebrity magazine such as 'Quem' ('Who'), which also belongs to Globo corporation. This kind of synergistic relationship between products, which arguably is a general characteristic of Brazilian celebrity products, can also be seen in magazines. Most celebrity magazines - whether or not belonging to Globo - feature Globo's stars on their covers, which shows its centrality in Brazilian mass culture productions.

The popularity of actors and actresses who star in these telenovelas in Brazil is therefore overwhelming. Besides having their images exposed to audiences of many millions of people spread all over the country six nights a week up to nine months, they are also special guests at talk shows as well as other variety products, get covered in dozens of specialized celebrity magazines and are often seen in advertising campaigns. Their position in this Brazilian star system also becomes evident in the amount of fan mail they receive, constantly mentioned in celebrity magazines as a sign of their status.

\section{Methodology}

The data analyzed here is a set of fan letters received by one actor and one actress who are both stars of telenovelas. By the time they were interviewed for the research mentioned above (Coelho 1999), they were both young (between twenty 
and thirty years old) and were at different career stages: while the actress had already been a telenovela star for several years, the actor was making his début as a star in a prime-time telenovela, having been hailed as a new sensation in his first appearance. They themselves gave their mail to me. The way this mail was disposed of by them present an aspect that is in itself very revealing of the way the actor and actress related to the audience: most of the mail was handed over unopened to me.

The fact that the mail had not been opened also suggests that there was no kind of previous selection by the two actors. There were about 200 letters sent to the actress and about 80 letters sent to the actor. This discrepancy in the amount of letters does not however imply different degrees of fame or prestige, since there was no kind of suggestion made by the researcher of any ideal number of letters or any concern by them about whether this number was enough or too much. These were just what they had at hand, since most of the fan mail is sent to Globo's studios and none of them (here included other actors and actresses also interviewed by me) showed any interest in getting their mail. This is an attitude best illustrated by the fact that, among ten actors and actresses interviewed, these were the only ones who had any fan mail at home to give to me.

This should not, however, be taken as suggestive of a lack of attention on the part of the researcher to the issue of representativeness of this material. The lack of interest, both on the part of the actors and actresses and - at least up to that moment - also on the part of the network in having any kind of evaluation of this form of audience response makes any attempt of accounting for the representativeness of these letters virtually impossible. This is not, however, merely a handicap; it is also illustrative of the nature of the relation established between these Brazilian telenovela stars and their fans. And what it is suggestive of is precisely the fact that there is indeed a star system revolving around this television genre and its stars, for the essence of fame, it could be argued, is the indifference of the famous for those who make them so. As Elias Canetti, albeit rather sardonically, puts it:

While one cares about the owners of the mouths who pronounce names, while he seduces them, corrupts them, entices them or mistreats them, he is not yet fully a celebrity. In this case, he does nothing but to prepare the foundations for his future army of shadows. Once it is attained, glory can allow itself not to worry about others, without bringing with it any kind of loss upon itself. $7(1983,442)$

It is therefore in a qualitative approach devoted to an understanding of the nature of fan-idol relation in this Brazilian star system that this data is examined. The letters were collected between 1991-1992, at the same time as I was doing the interviews 
mentioned above, with actors and actresses who worked at Rede Globo. I undertook a textual analysis, attempting to identify which discourses and strategies were recurrently used by fans attempting to achieve what I mentioned above as seeming to be their main purpose: to prove themselves as unique individuals.

\section{A painful paradox: a choir of unique individuals}

Almost three hundred fan letters compose a set that may strike a reader for its resemblance. Despite stylistic differences, the impression they elicit when read together is that of a repetition of one single theme: the desire to prove to the idol one is not a common individual, therefore deserving his or her attention. It is, however, precisely this recurrent effort that imprisons fans in a painful paradox: what makes them all the more alike is exactly their effort to prove themselves otherwise, that is, to assert their uniqueness. ${ }^{8}$ Nevertheless, this paradox is a theoretical construction elaborated by a social scientist. A fan who writes to his or her idol may for instance be both unaware and unconcerned about this dilemma. However, the ambivalence implicit in having at the same time a recognition of belonging to a crowd of anonymous individuals and being certain of his or her uniqueness as an individual can be noticed in some letters, such as in the examples below.

In the first one, the fan writes: 'I hope my letter gets to you soon, before the other fans bury you with their letters.' In this letter, the fan demonstrates perfect knowledge of stardom's dynamics. The actor she addresses has just made his début in television, being acclaimed as a rising star. She therefore knows he will be getting thousands of letters. Her hope is that if she hurries her letter will be among the first ones he gets, which might entitle her to his attention. She however does not seem to notice that her letter, among countless others, is part of the tide of letters under which she knows he will soon be buried.

The second example points to the same ambivalence. Another fan writes to the same actor: 'I know it is hard for you to answer these letters, for there are many of them. But, please, take just five minutes TO ANSWER MINE' [the use of capital letters is the fan's]. That is, the fan knows it is hard for the actor to answer all the letters he gets, but that does not seem to apply to hers. This ambivalence is however subtle and infrequent in these letters. Attempts to prove one's uniqueness are pervasive. I would like to discuss here two strategies most frequently used by fans to establish themselves as unique individuals: the resort both to the expression 'number one fan' and to romantic discourse to express their feelings. 


\section{A number of number one fans}

To present oneself as a 'number one fan' is illustrative of a set of strategies devoted to win the idol's attention by convincing him or her that one is not a common individual. However, the fans know they cannot take this recognition for granted. He or she therefore worries that his or her letter may not get to the idol and tries a number of strategies to be sure it does. A common feeling is that of suspicion that to address the letter to Rede Globo is to write in vain; some fans therefore ask for the actors' home address or phone number. An example of this fear is expressed by a fan who writes: 'You tell me a place where I can write to and where only my letter will be sent to.'

The second step is to guarantee some kind of response for reassurance that one's letter has been received and read. In an effort to obtain some kind of relief of this doubt, the fans beg for any kind of answer, in this process demanding less and less. They want an answer not for itself, but as a means to know their letters were read. It does not matter what the answer says; what matters is simply getting an answer. Fans therefore seem to give up most requests, asking just for a letter written in the actor's own handwriting; or with his signature 'so they can be sure the answer is his'; 'a letter with two sentences is enough' or 'just one sentence'; one asks for a letter saying just 'hi and bye' and one even - apparently unaware of this - asks for an autograph when suggesting he would be satisfied with 'your name on a piece of paper'. The best synthesis of this urge is exemplified by a fan who asks just for an envelope, explaining: 'there is no need to put anything inside it, it is good enough just to know it has been touched by your hands'.

Despite all these variations on the theme of their own uniqueness, these fans seem to have a favourite strategy: about $20 \%$ of the letters resort to the precise expression 'number one fan' to define who they are. There are also several variations of it: 'eternal fan', 'big fan', 'biggest fan', 'super-fan' or even more elaborated ones, such as 'number zero fan' (followed by an explanation that 'zero comes before one') or 'number two fan' (admitting that to be 'number one' is the actress's mother's prerogative).

The concurrent use by so many individuals of the same expression to convey their feelings of being unique leads us to the core of the paradox outlined above. It is precisely this claim of having their uniqueness recognized that returns fans to their condition of alikeness. What does this paradox tell us about this experience of fandom?

Massimo Canevacci (1990) draws upon Gregory Bateson's concept of 'double bind' to suggest a model for the understanding of how mass media's messages are constructed. By 'double bind' Bateson meant a kind of relation where two people are bound to one another by two contradictory messages that are nevertheless 
simultaneously sent and answered. Canevacci suggests it is precisely this kind of bind that mass media establishes with its audience. Among possible instances of this process, he mentions the concurrence of praising and insulting embodied in advertising that guarantees the consumer will be beautiful if she wears the product: she can be beautiful with it, she is ugly without it. Other examples would be incentives both to spend and to spare; exhortations to 'think for oneself, which, if followed, contradict themselves, etc.

What Canevacci suggests is then the existence of a model for the construction of messages exchanged between mass media and its audience. His point is that messages elaborated and communicated through mass media would establish a 'double bind' relationship with their audience. But the paradox of a choir of individuals claiming to be 'number one fans' can shed further light on this analysis. It can show us that this model of elaborating messages is not merely a model, but also has an essential content.

When mass media messages exhort individuals to assert their uniqueness, they do so collectively; this exhortation is addressed to crowds, not to specific individuals. It does not, however, assume itself to be so; mass media talk to all as if they were talking to one. It is precisely in this ambiguity that lie both its strength and its vulnerability; for each individual listens to a message elaborated as if for oneself, but addressed to all. And each one experiences his answer - the reassurance of his uniqueness - as spontaneous and particular.

\section{Similar experiences and emotional translations}

These letters are invariably affectionate. The nature of this affection vary, ranging from admiration to love, often openly disclosed. A few examples extracted from the letters: 'the characters you play are just like you, sweet, kind'; 'A character reveals a lot about the human being who plays it; if it were not so, how could we then explain this charisma of yours in the way you smile, you move, you talk?'; 'I can't even imagine what I would do if I saw you passing by, maybe experience a strong emotion for being close to someone I love so much, or a burst of tears or maybe fainting'; 'I met you here, in a play (...) in a situation kind of unpleasant, for you were crying. I was sort of sad, but you were very nice and kind. I took pictures of you and you gave me two autographs. I adore you!'; 'This letter's real intention is to let you know that you have achieved a bond with me that I myself cannot explain'.

If one focuses, however, not on the nature of the feeling which is expressed, but on the features of the relationship commonly established upon this feeling, the imbalance of romantic discourse becomes evident. What might often be seen as the ideal relationship based on feelings of love is reciprocal and exclusive; the fan- 
idol relationship is asymmetrical and non-exclusive by nature. Why, then, do fans resort to romantic discourse to express their feelings for their idols?

In an article devoted to an analysis of the conception of love implicit in Shakespeare's Romeo and Juliet, Ricardo B. deAraujo and Eduardo Viveiros de Castro (1977) point out that love in this tragedy is portrayed as a feeling that arises between two individuals, understood as unique individuals who relate to each other in complete indifference to any social constraints. It is a relation between psychological subjects, and not between personae. To be in love is therefore to assure and be assured of one's own uniqueness. Araujo and Castro suggest Shakespeare's tragedy can be understood as a modern myth, playing the role of a matrix for modern romantic relationships. If so, the resort to romantic discourse by fans to express their feelings for their idols could be seen as another way to assert their uniqueness, constituting therefore but another version of the yearn to be recognized as an individual, much in the same way as proclaiming to be 'a number one fan'.

But such an explanation leaves unanswered the question as to the incongruence of combining romantic discourse and fan-idol relationship (which can be thought of as a kind of charismatic relationship). In order to provide an explanation for that, I now turn to three ideas: Marcel Mauss's understanding of the expression of emotions as a socially constructed process; Charles Lindholm's comparison between love and charisma; and Edgar Morin's conception of the cultural industry's productions as models for interpreting private experiences.

In a classic sociological piece, Mauss (1981) examines a set of Australian funerary rites in order to discuss the tension between native experience of grief as something spontaneous that would flow from within each individual and the perception of the socially codified nature of its expression. He asserts that the role society plays in the individual's emotional life goes far beyond merely codifying its expression; it also allows him to understand the nature of his feelings. As he puts it: 'a person therefore does more than expressing his feelings; she expresses them to others, for she has to do so. She expresses them to herself by expressing them to others...' $(1981,332) .9$ In talking about love to his idol, a fan would thus be explaining to herself the nature of her feelings as love. But why talk of love, instead of, for instance, a feeling of fascination?

In order to understand this, we must now turn to Lindholm's comparison between love and charisma. His point is that there are one major similarity and one major difference between these two emotional experiences. They are very close in their capacity to provide individuals with an experience of fusionist nature, allowing a feeling of deep reunion with another. They would therefore be mutually exclusive; while one could experience both feelings during a lifetime, it would be impossible 
to be in love and involved in a charismatic relationship at the same time. And that would be so not because one could not have both at the same time, but because one needs not, for the urge for reunion (what Freud called an 'oceanic sentiment') would already be satisfied by either one of these emotional experiences.

Although alike in the nature of the desire they satisfy, these feelings differ deeply in the way they are conceived of in Western contemporary mass societies. For while to be in love is the utmost experience of all, to be a follower in a charismatic relationship (of which a fan would be a mere version) is vastly condemned. In order to confirm these differentiated social evaluations of love and charisma, one needs only to think of many twentieth century's Hollywood movies' major themes: people in love are portrayed as heroes (as Morin 1984, puts it), while fans are generally depicted as psychologically disturbed individuals, usually doomed to an unhappy end (Coelho 1999). ${ }^{10}$

We turn now to the last piece of this puzzle. As Morin puts it, the cultural industry is a 'school for the interpretation of experiences', providing models which individuals use to understand what they feel. Consequently, these Hollywood movies' audiences (and one should remember that Brazilians also consume these movies) learn that to be in love is morally eligible, while to be fascinated is to be condemned. How could a fan then deal emotionally with the idea of being the latter?

What I would like to suggest here is that a fan deals with it by denying it is so, asserting instead it is love. For love is an experience akin to charisma, attending as Lindholm put it - to the same primary emotional need. Its specific discourse is therefore at hand to be expropriated by fans in order to allow a translation through which to see themselves in a different and better light (expressing to others in order to express to themselves, as Mauss put it): not as fans but as people in love unique individuals, Western modern heroes.

\section{Learning with continuities: remarks on Brazil's place among Western societies}

The outline of this Brazilian experience of fandom sketched above has in its core a paradox between uniqueness and alikeness. It seems to echo themes that are pervasive in theories about modernity. Among early sociologists who have proposed a diagnosis of modernity, Simmel's approach of modern times seems particularly fit as a background against which to exam the fandom paradox, as his approach draws upon a conception of human condition as torn apart by two contradictory tendencies which would coexist in every human being: the need to be the same and the desire to be different (Figueira 1981). 
Human societies are thus obliged to find a modus vivendi in which both needs can be attended to. They differ, however, in the balance they are able to reach between these two human tendencies; some provide more opportunities for the individual to experience belonging - being the same -, while others are more successful in creating opportunities for the experience of a sense of uniqueness - being different. The last would be the case in modern societies, due to the fragmentation of groups that characterize life in its natural habitat: the metropolis (Simmel 1987). Individuals in modern societies would thus have an accentuated feeling of uniqueness, which points to a view of modernity that has as its main characteristic the unbalance towards being different.

This kind of approach to modernity that revolves around its particular configuration of individual experience is pervasive in social theories. It can also be found in Bauman's analysis of the modern yearn for community. For him, 'community' is a word associated with everything commonly missed by modern men, who long for sympathy, trust, and security, feeling constantly threatened by features attributed to modernity - competition and indifference. This longing for community is however caught in a paradox: the fact that in order to achieve a sense of belonging, one must give up some measure of freedom. And here we meet again with an old acquaintance: the opposition already discussed by Freud in Civilization and its Discontents, where he pointed to this human drama embodied in the necessary choice between freedom and security (Bauman 2003).

Going from Simmel to Bauman only to meet with Freud again speaks eloquently about how crucial this issue of belonging-differing has been to the understanding of modern times. Those theories were however based on an observation of modern European life and were meant to explain these observed societies. What happens then if they can prove themselves useful for the understanding of other societies which have been excluded, by precisely the same intellectual matrix, as standing outside its scope?

Brazilian social thought has traditionally searched for an understanding of Brazilian society devoted to a description of its singularity. In this search, the issue of hierarchy has been given a central place. It is the case in one of the major classical interpretations of Brazilian society, Gilberto Freyre's The Masters and the Slaves (1983, first published in 1933), where he presents Brazil as a hierarchical society whose historical and strong antagonisms - mainly that between masters and slaves - would have been softened by racial miscegenation.

In the eighties, the issue of the place occupied by hierarchy in Brazilian society has been re-elaborated in an interpretation that, although much more recent, has already won its place in the history of Brazilian social thought: that of Roberto DaMatta's Carnivals, Rogues, and Heroes: An Interpretation of the Brazilian Dilemma 
(1978). DaMatta sketches a view of Brazil as a society caught in an oscillation between a hierarchical reality and an egalitarian ideal. This egalitarian ideal would place it among Western modern nations, being however an importation.

At least since Malinowski, however, we know that ideas, even when incongruent to daily practices, are not masks to be unveiled, but intrinsic parts of this very same reality, for to experience hierarchical practices which are thought of as legitimate is something very different from the experience of similar hierarchical practices condemned by discourses of daily life. This kind of approach to Brazilian society would then entitle Brazilian social sciences to resort to theoretical models elaborated within foreign intellectual trends, since its status as a former colony places it at the same time as different and similar to the colonizing metropolis, for it makes it part of Western history. European intellectual traditions, however - and one could also include here North American social sciences -, usually think of nations such as Brazil in terms of their singularities.

What I suggest here is to shift the focus to what Brazil shares with Western societies. I try to do so by exploring these theoretical models' profitability for the understanding of Brazilian reality. Needless to say, these models need to go through a filter in order to be applied to social realities outside of their original contexts. In a world so strongly defined by mass phenomena and globalization, it is crucial that social sciences learn how to deal with continuities and similarities. The common sense view of globalization as producing an undesirable erasing of cultural diversity and its twin sister counter-argument that asserts the ability of particular cultures to impose themselves through re-signification have not been leaving much room to a theoretically responsible attention to the meaning of similarities among Western societies.

\section{Conclusion}

Celebrity and fandom, by their very nature byproducts of massification and globalization, are key issues for further exploration of the problems here outlined. If in a globalized world they may be thought of as universal phenomena, case studies devoted to an apprehension of particularities can allow a comparison of both what is different and what is shared, therefore providing a way to a deeper understanding of complexities of Western modernity. Among these complexities, the issue of how South American contemporary societies may be thought of as sharing broader Western modern life's features stands out for its centrality. These features can at the same time be perceived of as showing that these societies belong to Western modernity while also suggesting that they have particularities, as their specific social configurations of the fundamental tension between being equal and being unique can show. 
In a study on celebrity culture in the United States, Joshua Gamson (1994) examines what he calls 'celebrity texts' - such as celebrity magazines - and suggests that throughout the twentieth century there has been a shift from stories about fame achieved by the talented and deserving to tales about the so-called 'celebrities' - those who are known 'not for doing but for being'. The author undertakes an analysis where the three main characters in celebrity production are discussed - texts, producers and audiences. And he concludes by suggesting that '...celebrity culture is itself built on major American fault lines: simultaneous pulls on the parts of producers and audiences alike to celebrate individual distinction and the equality of all, to demonstrate that success is available to all and available only to the special, to instate and to undermine a meritocratic hierarchy, to embrace and attack authority' (Ibid, 11-12, my italics). His reasoning goes on to an exploration of the influence entertainment celebrity's culture has on political celebrities in North America's democracy, where he reaffirms fame discourse to be permeated by an ambivalence which has as one of its trends 'a concurrent promotion of and distaste for equality' (Ibid, 195).

The resemblance between this aspect of Gamson's analysis of North American culture of celebrity and the interpretation outlined here of Brazilian fans' yearn for singularization as a tension between equality and uniqueness is an argument both in favor of case studies of fandom (and other aspects of the experience of fame) and of comparative research on fame and celebrity across modern societies. Brazilian social sciences, however, have not devoted much attention to celebrity (as defined by Gamson). That could be understood as a mere symptom of the fact that what can be regarded as an increased media attention upon celebrity is a relatively recent phenomenon in Brazil. The stars of telenovelas could perhaps be seen as the beginning of an increasing emphasis on celebrity in Brazilian culture, more recently accelerated by a growth of celebrity magazines and the introduction of the first reality show aired in Brazilian television: 'No Limite' (Brazilian most successful version of Endemol's 'Survivor') aired by Globo in 2000. Brazilian 'celebrities' in Gamson's sense can be thought of as coming mostly from these reality shows, which, due perhaps to its very recent appearance in Brazilian television, could account for the up to now relatively sparse attention of Brazilian social sciences to this phenomenon. ${ }^{11}$

Case studies such as this here presented, in its effort to describe and explain how a particular form in which fandom is experienced - the letters addressed to television stars - provides a way of further exploring how this tension between equality and singularity achieve particular forms in specific societies. Other case studies, which for instance undertake comparisons of the public image of celebrities from different cultures - either within South America or crossing the bridge between Europe and South America ${ }^{12}$ - can also provide insightful leads to this endeavour. Another promising kind of analysis would be to approach the way 
international stars are consumed in particular societies, as is the case with the Madonna's fan club study mentioned in the introduction.

The experience of fame - as portrayed in several mass media products or as experienced in a number of ways - can thus be an extremely fertile ground for reflections about modernity, for it stands precisely in the center of one of its main aspects: the ubiquity of mass media and its place in the configuration of the condition of the modern individual.

\section{Notes}

${ }^{1}$ I would like to thank Claudia Barcellos Rezende, Bianca Freire-Medeiros and Helena Bomeny for their helpful comments on this paper.

2 The band is Biquini Cavadão and the song is called "Zé Ninguém" ("John Doe"). I quote here the lyrics in the translation made for the English subtitles in the band's DVD Biquini Cavadão ao Vivo, released in 2005.

3 Brazilian studies of fame can also be found in the broader field of the anthropology of mass communication. A strong tendency in this area of studies is the exploration of the usefulness of classical notions of myths and rituals to the understanding of mass culture products. See Rocha's (1985) study of Brazilian advertising, Coelho's (1995) study of public opinion scandals related to sex crimes and, in a more specifically fame-related work, Rodrigues's (1991) examination of media coverage on the death of celebrities and Coelho's (1995) analysis of versions of "A Star is Born". A third trend where Brazilian social sciences has attended to fame and celebrity are within case studies on the construction of public images. Examples can be seen in Helal and Coelho's (1996) study on the media's edition of soccer player Sávio, Guedes' (1995) study on the values associated to Romario's public image; Helal and Murad's (1995) comparison between Garrincha and Maradona's public images; Dantas Pinto's (2005) dissertation on the place of death in rock singers' biographies (undertaking a comparison between Kurt Cobain and Renato Russo - a Brazilian pop singer); and Dantas Pinto's (forthcoming) study on Roberto Carlos' (another Brazilian pop singer) public image.

4 This research was later published as a book by Editora da Fundação Getúlio Vargas (Coelho, 1999). It also included an analysis of movies about fame and celebrity and of the experience of fame as commented upon by actors and actresses interviewed by me.

${ }^{5}$ Some of the ideas presented in this section were originally published in a lengthier version in Coelho (1999).

${ }^{6}$ I use here the term "celebrity" to refer to any famous individual, regardless of the reasons for its fame.

7 Translated from the Brazilian translation.

8 The paradox focused upon in this paper is however only one aspect of fandom. There are other ways to experience fandom which do not represent the isolated 
mood outlined here, such as those reported by fans belonging to fan clubs. In these circumstances fandom can be exercised in quite an opposite way (for an ethnographic account of a fan club's party, see Coralis (2004)). An alternative mode of looking at these fan letters would be as a kind of diary, as an attempt to elaborate their own feelings which may not necessarily involve an actual desire of establishing a relationship with the idol. I would like to thank the anonymous reviewer of $W P C C$ for this suggestion.

${ }^{9}$ Translated from the Brazilian translation.

${ }^{10}$ For an analysis of how fans and fandom are depicted in a set of Hollywood movies, see Lewis (1992). Jenson's work (1992) also corroborates this perception of the negative way fans are seen in Western popular culture through her analysis of two main images of the fan - the lonely individual and the hysterical crowd.

${ }^{11}$ For a very recent work on reality shows aired at Brazilian cable television, see Freire-Medeiros and Bakker (forthcoming).

12 See for example Helal and Murad (1995) and Pinto (2005) for such comparisons.

\section{References}

Araujo, R. B. de and Castro, E. V. de (1977) 'Romeu e Julieta e a Origem do Estado', in G. Velho (ed.) Arte e Sociedade, Rio de Janeiro: Zahar, pp. 130-169.

Bauman, Z. (2003) Comunidade - a busca por segurança no mundo atual, Rio de Janeiro: Jorge Zahar.

Borelli, S. and Priolli, G. (eds.) (2000) A Deusa Ferida, São Paulo: Summus.

Coralis, P. (2004) "Nunca te vi, sempre te amei: uma análise antropológica da idolatria a Madonna em um fã-clube virtual”. Dissertation presented to Programa de Pós-Graduação em Ciências Sociais da Universidade do Estado do Rio de Janeiro.

Canetti, E. (1983) Massa e Poder, São Paulo: Melhoramentos; Brasília: UnB.

Canevacci, M. (1990) Antropologia da Comunicaşão Visual, São Paulo: Brasiliense.

Coelho, M. C. (1999) A Experiência da Fama - individualismo e comunicação de massa, Rio de Janeiro: Editora FGV. - (1995) 'Rituals, Scandals and Sex Crimes: attempted-rape murders across two generations', in D. Hess and R. DaMatta (eds.) The Brazilian Puzzle, New York: Columbia University Press, pp. 89-113.

- (1995) 'Nasce uma Estrela: a indústria cultural e os discursos contemporâneos', Cadernos de Antropologia e Imagem 5: 123-134.

DaMatta, R. (1978) Carnavais, Malandros e Heróis, Rio de Janeiro: Zahar.

Dantas Pinto, P. H. (2005) "A Construção da Eternidade: indústria cultural e mitologia na sociedade moderna". Dissertation presented to Programa de Pós-Graduação em Ciências Sociais da Universidade do Estado do Rio de Janeiro. - (forthcoming) 'A majestade assegurada: uma leitura da trajetória de

Roberto Carlos', Cadernos de Antropologia e Imagem 20.

Eco, U. (1979) Apocalípticos e Integrados, São Paulo: Perspectiva. 
Figueira, S. (1981) O Contexto Social da Psicanálise, Rio de Janeiro: Francisco Alves. Freire-Medeiros, B. and Bakker, A. (forthcoming) 'Televisão-Realidade e metamorfose identitária em Extreme Makeover', Cadernos de Antropologia e Imagem 20.

Freyre, G. (1983 [1933]) Casa-Grande \& Senzala, Rio de Janeiro: Livraria José Olympio Editora.

Gamson, J. (1994) Claims to Fame - celebrity in contemporary America, Berkeley: University of California Press.

Guedes, S. L. (1995) 'O Salvador da Pátria: considerações em torno da imagem do jogador Romário na Copa do Mundo de 1994', Pesquisa de Campo: Revista do Núcleo de Sociologia do Futebol 1: 23-41.

Helal, R. and Coelho, M. C. (1996) 'Mídia, Idolatria e Construção da Imagem Pública: um estudo de caso', Pesquisa de Campo: Revista do Núcleo de Sociologia do Futebol 3/4: 79-88.

Helal, R. and Murad, M. (1995) 'Alegria do Povo e Don Diego: um ensaio sociológico sobre o êxtase e a agonia de heróis do futebol', Pesquisa de Campo: Revista do Núcleo de Sociologia do Futebol 1: 63-79.

Jenson, J. (1992) "Fandom as Pathology: The Consequences of Characterization", in L. A. Lewis (ed.) The Adoring Audience, London and New York: Routledge, pp. 9-29.

Lewis, L. (1992) '"Something More Than Love': Fan Stories on Film", in L. A. Lewis (ed.) The Adoring Audience, London and New York: Routledge, pp. 135159.

Lindholm, C. (1993) Carisma, Rio de Janeiro: Jorge Zahar.

Mauss, M. (1981) 'A Expressão Obrigatória dos Sentimentos’, in Ensaios de Sociologia, São Paulo: Perspectiva.

Morin, E. (1984) Cultura de massas no século XX, Rio de Janeiro: ForenseUniversitária. . (1980) As Estrelas de Cinema, Lisboa: Livros Horizonte.

Rezende, C. B. (2004) 'Ser Brasileiro: identidade nacional e subjetividade entre acadêmicos', Intersecõos - revista de estudos interdisciplinares 6 (2), pp. 293-310.

Rodrigues, J. C. (1992) 'Quando a Morte é Festa', in Ensaios em Antropologia do Poder, Rio de Janeiro: Terra Nova, pp. 55-73.

Simmel, G. (1987) 'A Metrópole e a Vida Mental', in O. Velho (ed.) O Fenômeno Urbano, Rio de Janeiro: Guanabara.

Teixeira, R. da C. (2004) “Krig-Há, Bandolo! Cuidado, aí vem Raul Seixas.” PhD Thesis presented to Programa de Pós-Graduação em Sociologia e Antropologia do Instituto de Filosofia e Ciências Sociais da Universidade Federal do Rio de Janeiro. 